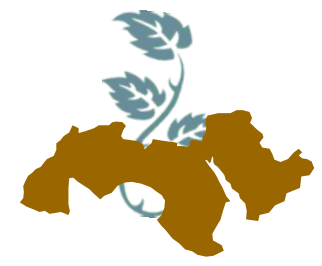

\title{
METABOLIC CHANGES OF CUCUMBER PLANTS DUE TO TWO CMV EGYPTIAN ISOLATES
}

\author{
$[150]$ \\ Farahat ${ }^{1}$ A.S., El-Morsi ${ }^{1}$ A.A., Soweha ${ }^{1}$ H.E., Sofy ${ }^{2}$ A.R. and Refaey $^{2}$ E.E. \\ 1- Botany Dept., Fac. of Sci., Al-Mansoura Univ., Al-Mansoura, Egypt \\ 2- Botany and Microbiology Dept., Fac. of Sci., Al-Azhar Univ., 11884 Nasr City, Cairo, Egypt
}

Keywords: Cucumber plants, Cucumber mosaic virus, oxidative enzymes, biochemical, CMV isolates, ELISA.

\section{ABSTRACT}

Cucumber production exposed to huge losses in Egypt and worldwide due to infection with $\mathrm{Cu}$ cumber mosaic Cucumovirus (CMV). The current study focus on the impact of two Egyptian CMV isolates on metabolic and oxidative activities in cucumber plants. Two CMV isolates was obtained from cucurbitaceous crops and confirmed by DASELISA. Inoculated cucumber plants by infectious crude sap with two CMV isolates showed difference in external symptoms. The metabolic and biochemical components of cucumber plants were affected with two CMV isolates. The present study provided that, CMV infection caused a significant reduction in both photopigments and biochemical components while bioactive components (proline and phenol) and oxidative enzymes (POX, SOD, PPO and CAT) were increased significantly compared healthy ones. It was found that cucumberCMV isolate was more effective in metabolic and biochemical than Squash-CMV isolate.

\section{INTRODUCTION}

Viral diseases dynamical varying problems and caused major economic losses (Nameth et al 1986). Cucumber mosaic virus considers one of the most important pathogens affecting crops worldwide.

CMV is worldwide amongst the five most important plant viruses, infecting vegetable and ornamental species (Cornelia Heinze et al 2012).

(Received 25 March, 2018)

(Revised 28 March, 2018)

(Accepted 1 April, 2018)
CMV has one of the widest geographical deliveries of any plant virus, having been detected world-wide, both in tropical and moderate climates (Palukaitis et al 1992). CMV is one of the most destroyer and economically important plant viruses having nearly 365 genera, 85 families. The total harvest area for cucumber in Egypt up to 23046 Fadden in 2016 while was 20875 in 2014, and the production increased to 519858 ton in 2016 while was 473774 in 2014. (FAO, 2016).

CMV is a tripartite virus with abundant sequence variability; classified into three subgroups with 80 to $97 \%$ identical nucleotides in their coat protein (Cornelia Heinze et al 2012).

An affected biochemical changes in virus infected plants result in decrease of production quality of infected crops. Several investigators suggest that virus multiplication inside the plant cell alters biochemical ingredients of plants and disorder the physiological processes like transpiration, photosynthesis and respiration of the infected plants that affect the growth and crop (Tajul et al 2011; ElDougdoug et al 2014a and Sofy et al 2017). Also, have informed that the determination of cellular ingredients in virus infected plant is very important to comprehend the activities of the host cell and the nature and degree of damage have caused by the virus. Viral infection stimulates increased absorbency in cells to cause loss of water. These also illustrate the cup shape of the infected leaves, mainly in the severe symptom stages (Oleinikova, 1969). Physiological processes important for plant activities and growth (Arfan et al 2011), and it is highly affected by viral infection (Radwan et al 2010; Sofy et al 2014 and Sofy et al 2017). Several reports suggest that virus multiplication inside the plant cell disorder the physiological processes like respiration, photosynthesis and transpiration, also changes different biochemical constituents of 
the infected plants that affect the growth and yield (Tajul et al 2011; El-Dougdoug et al 2014b and Sofy et al 2017).

Carbohydrates, which mean one of the main organic components of the dry matter, derived from photosynthesis, were found to be affected by CMV and infected stress Moreover, a memorable reduction in the total protein was seen as a result of CMV infection. Infected cucumber plants accumulate more phenolic compounds as antioxidants to resist viral stress (El-Dougdoug et al 2010, 2014 and Sofy et al 2018). The current study focus on the impact of two Egyptian CMV isolates on metabolic and oxidative activities in cucumber plants

\section{MATERIALS AND METHODS}

\section{Source of cucumber plant and virus isolate}

Seeds of Cucumis sativus L. alfa-beta plants were obtained from Agriculture Research Centre, Ministry of Agriculture, Giza, Egypt, and germinated in seed trays containing perlite. Seedlings were cultivated under natural lighting, day/night temperature of approx. $22 / 20^{\circ} \mathrm{C}$ and $60 \%$ mean relative humidity. One week old seedlings were potted in soil and grown under the same conditions.

Cucumber seedlings were checked before planted, were tested against CMV, Watermelon Mosaic virus (WMV), Squash Mosaic virus (SqMV), and Cucumber Green Motel Virus (CGMV) by DAS-ELISA technique using specific polyclonal antibodies (Clark and Adam, 1977).

Two CMV viruses were detected in naturally infected cucumber and squash plants cultivated in Gharbia and Sharqia Governorates, and identified biologically, serologically and molecularly previously (Farahat, 2017) (unpublished).

\section{Experimental design}

Certified seedlings and virus tested against (CMV, CGMV, SqMV, and WMV). Two plants per pot were planted and inoculated mechanically with $\mathrm{CMV}$ isolates at two cotyledons on leaves. Another two plants was set without CMV inoculation as a control for the two isolates. The plant samples were collected for analysis when the plants were 40 days old. The inoculated plants were kept under greenhouse conditions and examined for symptoms appearance.
Serological detection was determined using CMV specific polyclonal antibodies by DAS-ELISA according to (Clark and Adam, 1977).

\section{Metabolic Changes \\ Photopigmens constants}

The method used for the quantitative determination of chlorophyll was that of Vernon and Selly (1966). The optical density of the plant extract was measured using spectrophotometer of two wave lengths $(649,665$ and $470 \mathrm{~nm})$ (Unico 2000).

$\mathrm{Mg}$ chlorophyll (a) $/ \mathrm{g}$ tissue $=11.63(\mathrm{~A} 665)-2.39$ (A649).

Mg chlorophyll (b) / g tissue $=20.11($ A649) 5.18(A665).

Mg chlorophyll $(\mathrm{a}+\mathrm{b}) / \mathrm{g}$ tissue $=6.45(\mathrm{A665})$ +17.72(A649).

For carotenoids, equation: $\mathrm{Car}_{\mathrm{x}+\mathrm{c}}=1000 \times\left(\mathrm{OD}_{470^{-}}\right.$ $\left.1.82 \mathrm{C}_{\mathrm{a}}-85.02 \mathrm{C}_{\mathrm{b}}\right) / 198=\mathrm{mg} / \mathrm{g}$ fresh weight.

Total soluble carbohydrates: Total soluble carbohydrates were determined using anthrone techniques according to (Umbriet et al 1969), and measured (in terms of sucrose equivalents) using spectrophotometer at $620 \mathrm{~nm}$ (Unico 2000).

Phenolic compounds: Phenolic compounds in leaves were carried out according to the method described by (Daniel and George, 1972). Using spectrophotometer (Unico 2000) at the wave length $725 \mathrm{~nm}$.

Free proline: Free proline content was determined according to the method described by (Bates et al 1973) at $520 \mathrm{~nm}$ using UV- spectrophotometer (Unico 2000).

Total proteins: According to the method of (Lowery et al 1951) using casein as a standard protein determination of total protein in leaves by spectrophotometer (Unico2000) at the wave length 750 $\mathrm{nm}$.

Antioxidant enzyme activates: were estimation according to (MuKherjee and Choudhuri, 1983).

Superoxide dismutase (SOD) activity: was determined by measuring the inhibition of the auto oxidation of pyrogallol using a method according to (Marklund and Marklund, 1974) at $325 \mathrm{~nm}$ using UV spectrophotometer (Unico2000). 
Catalase (CAT) activity: was determined by measuring the rate change of $\mathrm{H}_{2} \mathrm{O}_{2}$ absorbance with a UV spectrophotometer (Unico2000) at 250 $\mathrm{nm}$ according to the method of (Chen et al 2000).

Peroxidase (POX) activity: was assayed using the rate of increase in absorbance as pyrogallol was determined by UV- spectrophotometer (Unico2000) at $470 \mathrm{~nm}$ (Bergmeyer, 1974).

Polyphenol oxidase (PPO) activity: was determined according to the method adopted by Matta and Dimond (1963). The absorbance was measured at $495 \mathrm{~nm}$ by UV spectrophotometer (Unico2000).

\section{Statistical analysis:}

All statistical calculations were done using SPSS (statistical package for the social science version 20.00) statistical program at 0.05 level of probability Snedecor and Cochran (1973). Quantitative data with parametric distribution were done using analysis of variance the two-way ANOVA and Post hoc-LSD tests (the least significant difference). The confidence interval was set to $95 \%$ and the margin of error accepted was set to $5 \%$. The $p$-value was considered non-significant (NS) at the level of $>0.05$, significant at the level of $\leq 0.05$, 0.01 and highly significant at the level of $\leq 0.001$. The Pearson linear correlation coefficient, automatic and linear modelling and discriminant analysis were estimated to show the relationship between quantitative parameters Härdle and Simar (2007).

\section{RESULT}

Two CMV isolates were obtained from cucumber and squash naturally infected plants showing distinct sever viral like symptoms on cucumber plants while showing mild viral like symptoms on squash plants and conformed by DAS-ELISA using polyclonal antibody specific CMV kits.

The viral infectivity of two CMV isolates were confirmed through sap inoculated mechanically on healthy cucumber (Cucumis sativus L. alfa-beta) plants, that gave sever mosaic, blisters and malformation due to cucumber-CMV isolate while squash-CMV isolate showed mosaic and blisters. As well as gave (+ve) results with CMV polyclonal antibodies by DAS-ELISA.

\section{Photosynthetic pigments content}

Photosynthesis is the most vital metabolic processes of plant growth. The effects process in cucumber plant, and infected cucumber plant of two different $\mathrm{CMV}$ isolates showed verability responses by assessing the content of chlorophylls and carotenoids in cucumber plants leaves. Graphically data in Figure (1a, b, c \& d) reduce clarified clearly that, the contents of chlorophylls $(a, b$ and total $\mathrm{a}+\mathrm{b})$ and carotenoids were most significant reduction in cucumber plant compared with the healthy ones due to two CMV isolates infection.

Data generated (Fig. 1-c) revealed that contents of total chlorophyll in leaves were significantly decreased in infected cucumber leaves with Gharbia-CMV and Sharqia-CMV isolates by $45 \%$ and $31 \%$, respectively. 

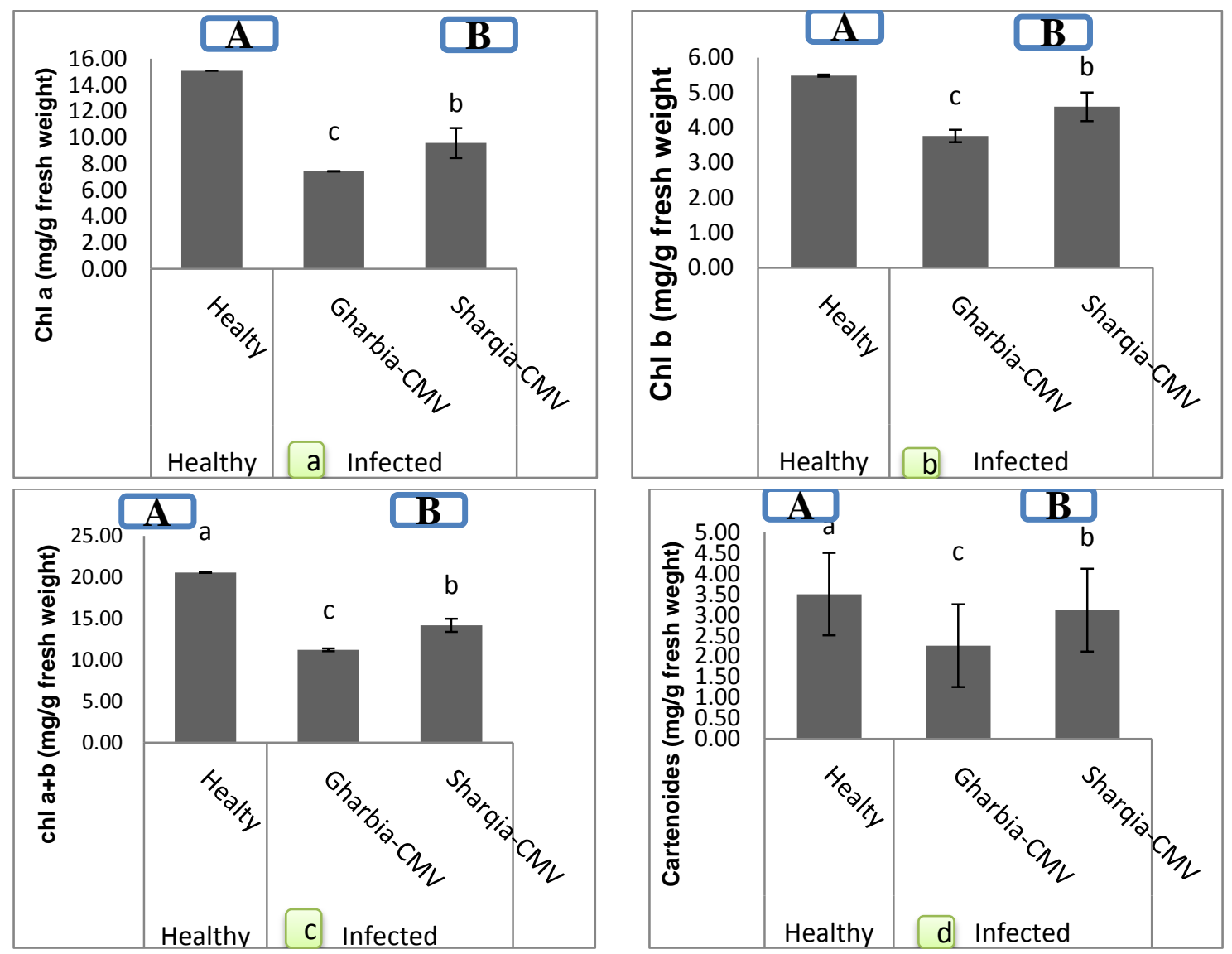

Fig. 1. Histogram showing the (a) chlorophyll a, (b) chlorophyll b, (c) chlorophyll $a+b$, and (d) carotenoids level of cucumber. Each value is mean of 6 replicates \pm standard error of means, Healthy= Healthy plants, Cucumber-CMV = Infected plants with Cucumber-CMV isolate, Squash-CMV=Infected plants with SquashCMV isolate.

\section{Biochemical and bioactive contents}

The carbohydrates and protein content in cucumber plant healthy and inoculated plant was noticed that difference responses as a result of CMV infection.

Data tableted in Fig. (2-a) significantly decreased in infected cucumber plants with Cucumber-CMV and Squash-CMV isolates by $32 \%$ and $21 \%$, respectively.

Regarding the effect of two different CMV isolates on total protein content, results in Fig. (2-b) showed significant reduction by $52 \%$ and $32 \%$ in the total protein contents in cucumber plants leaves that infected with CMV compared to the same healthy one throughout Gharbia-CMV and Sharqia-CMV isolates, respectively.
Phenols and proline were estimated in cucumber plants leaves. It was noticed that Cucumber plant showed different responses as a result of two different CMV infections.

Data presented in Figure (2-d) shown the effect of two different CMV isolates on total phenol content, results showed significantly increased in the total phenol contents in CMV infected plants compared to the same healthy one at tested cucumber plant, this incident generally throughout two different CMV isolates.

Concerning the impact of two different CMV isolates on total proline content, results in Figure (2-c) showed significantly increased in the total proline contents in cucumber plant leaves infected with CMV compared to the same healthy one throughout two CMV isolates. 


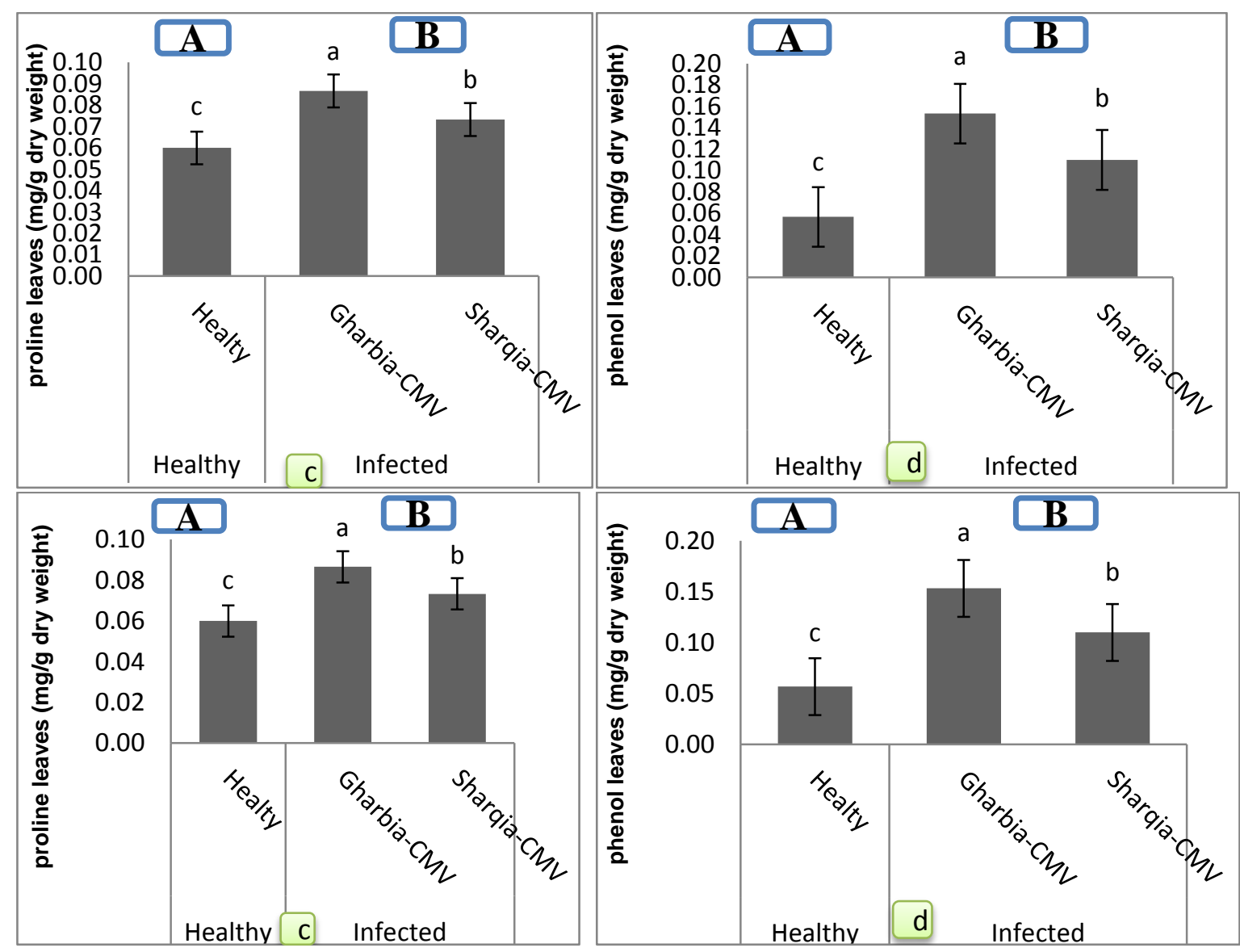

Fig. 2. Histogram showing the (a) carbohydrates, (b) protein, (c) proline and (d) phenol contents of cucumber plant. Each value is mean of 6 replicates \pm standard error of means, Healthy= Healthy plants, Cucumber-CMV = Infected plants with Cucumber-CMV isolate, Squash-CMV=Infected plants with Squash-CMV isolate.

The Gharbia-CMV isolate was more effective than Sharqia-CMV isolate concerning the phenol and proline content of cucumber plant infected that comparing with the same healthy one.

\section{Enzyme activities}

Plants employ antioxidants detoxifying enzymes activities to contend oxidative stress generated from biotic stress. The enzymatic activity of PPO, POX, CAT and SOD in cucumber plant under effect of two different CMV isolates was measured to determine the nature of the antioxidant responses of cucumber plant to CMV isolates action.

Cucumber plant indicated different variation in the enzyme activities under the influence of two different CMV isolates stress. Present work illustrated in generally that, infected cucumber plants with Gharbia-CMV and Sharqia-CMV isolates showed significantly increased in the antioxidant enzyme activity compared to the same healthy one.

Data presented in Figure (3-a), indicated the effect of two CMV isolates on POX activity, results showed significantly increased in the POX activity in Gharbia-CMV and Sharqia-CMV infected plants by $112 \%$ and $88 \%$, respectively, compared to the same healthy one.

The high activity of (PPO) was obtained generally, in infected cucumber plants throughout two CMV isolates compared with the same healthy cucumber plants. 
Data generated in Figure (3-c), showed the changes in the activities of CAT enzyme in cucumber leaves by increased more than four folds and three folds in response to Gharbia-CMV and Sharqia-CMV isolates infection, respectively.

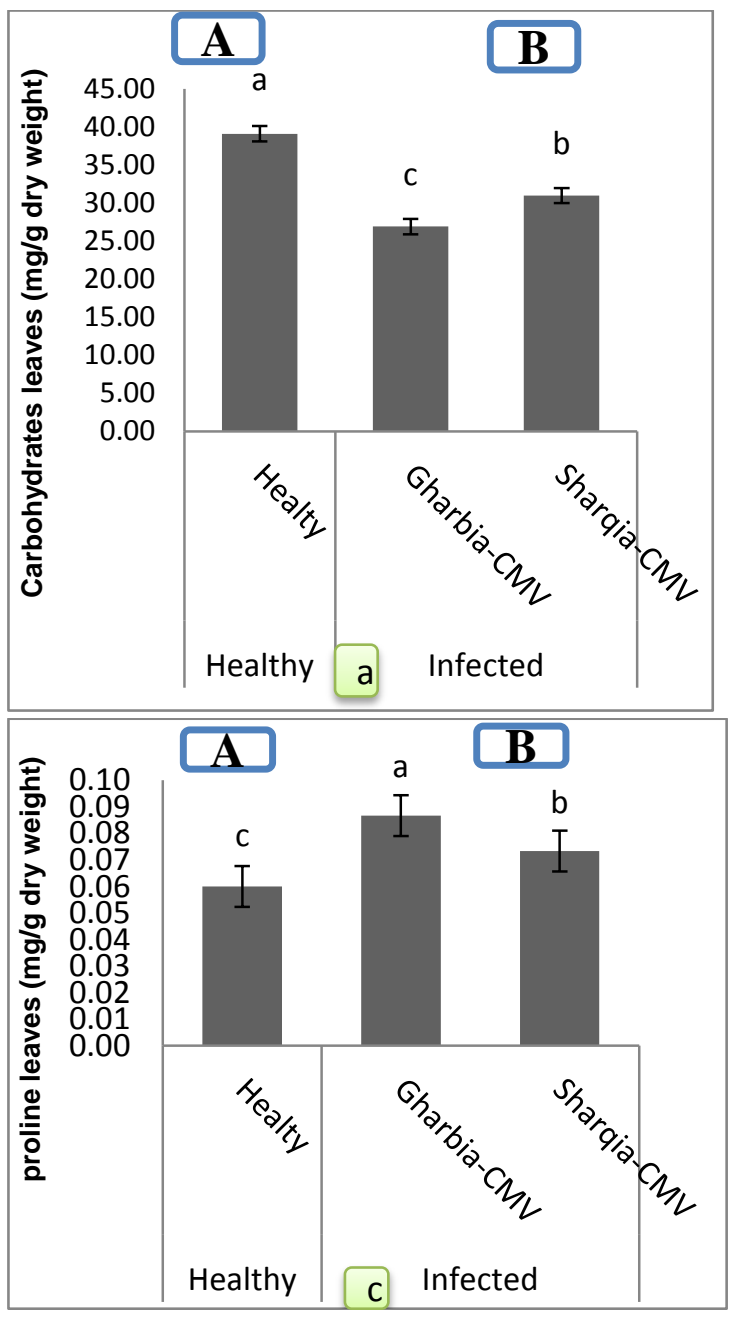

Concerning the effect on SOD activity due to Gharbia-CMV and Sharqia-CMV isolates infected plants, Figure (3-d) showed significant increase in the SOD activity by $41 \%$ and $29 \%$, respectively, compared to the same healthy one. Among two CMV isolates, the most vital impact on POX, PPO, CAT and SOD activities was Gharbia-CMV isolate.
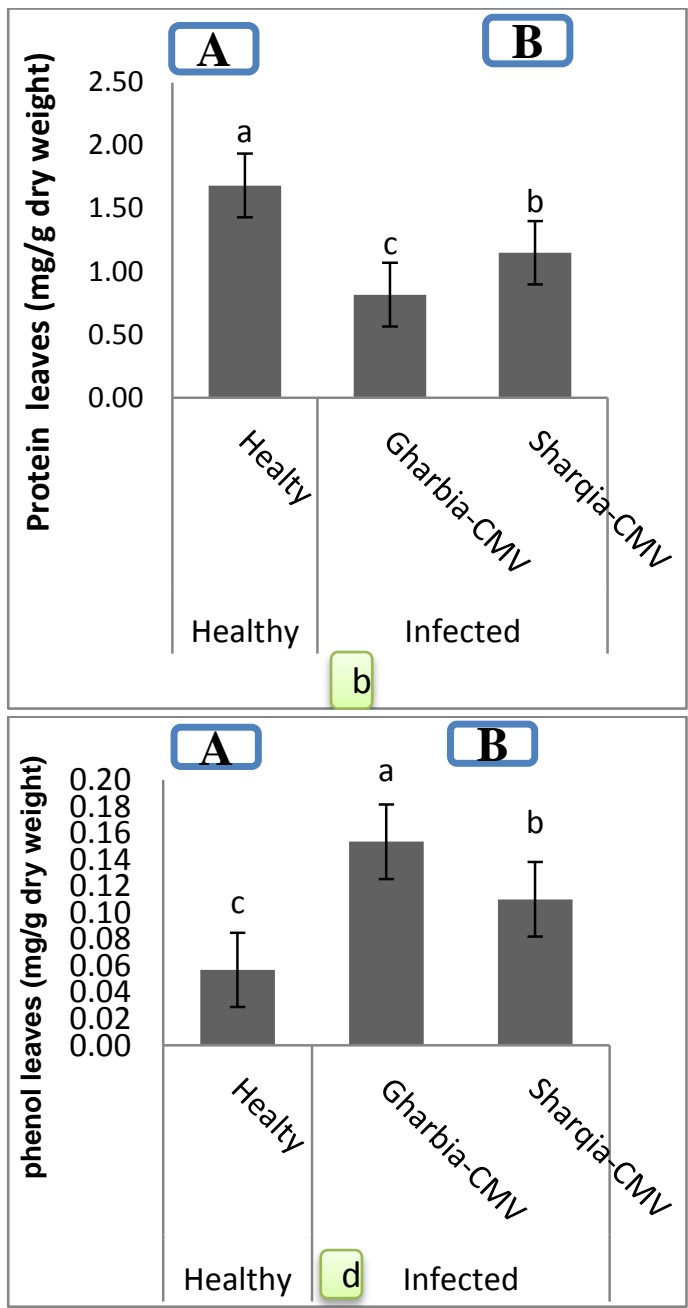

Fig. 3. Histogram showing the on (a) POX, (b) PPO, (c) CAT, and (d) SOD activities of cucumber plant. Each value is mean of 6 replicates \pm standard error of means, Healthy= Healthy plants, Cucumber-CMV = Infected plants with Cucumber-CMV isolate, Squash-CMV=Infected plants with Squash-CMV isolate

\section{DISCUSSION}

CMV has a wide distribution in Egypt as detected by (Sofy and Soliman, 2011; Sofy et al 2012).

In current study, both Cucumber-CMV and Squash-CMV isolates were able to induce symptoms when transmitted mechanically through crude sap to healthy plants but Cucumber-CMV isolate induce sever symptoms while Squash-CMV isolate induce mild symptoms.

At the same time, the two different CMV isolates retorted positively with specific antibodies by applying the DAS-ELISA assay. These results are supported by (Sofy et al 2018). 
Biochemical changes in cucumber plant tissues related to CMV infection as a reduction in the concentration of photosynthetic pigment levels (chlorophyll $a$, chlorophyll b, total chlorophylls and carotenoids). The current study is in agreement with the study carried by (Sofy et al 2018) who told that the decrease in photosynthetic pigments may be attributed to the infected of CMV on biosynthesis of pigments.

Decreased in carbohydrates level in leaves were regarded to be due to CMV isolates infected of cucumber plant as compared to healthy ones; this may be due to the resistance effect of the plant against the infection of virus where the strategy changes from defensive to survival. These results are in agreement with the study carried by (Gupta et al 2010, Montasser et al 2012, and Khalil et al 2014).

Decreased in total protein level in leaves were regarded to be due to CMV isolates infected of tested plant as compared to healthy ones. This observation also was reported for cucumber plants infected with Cucumber Mosaic virus (Sofy et al 2018). The total protein decrease was detected also in infected carrot (Daucus carota L.) plant (Afreen 2011).

Total phenols act as a significant role in the organizing of plant metabolic process and at all plant growth as well as lignin synthesis (Kumar et al 2010). As well, phenols act as free radical as well as substrates for several antioxidant enzymes (Martin-Tanguy, 2001). Also a number of phenols are considered as pre-infection inhibitors, supplying the plant with a degree of basic resistance against pathogenic micro-organisms. Increased in phenol content level in leaves was regarded to be due to CMV isolates infected of tested plant as compared to healthy ones. This result was agreed with studies reported by (El-Dougdoug et al 2013; Khalil et al 2014 and Sofy et al 2017). Previous studies suggest that stressed tomato plants accumulate more phenolic compounds as antioxidants to resist viral stress (Hutson and Smith, 1980).

Pathogen infection may effect on the activation of numerous compounds in the cell as the proline production. The obtained results increased in total proline level in leaves and this was regarded to be due to CMV isolates infected of tested plant as compared to healthy ones. These results are agreement with (Sofy et al 2017) they reported that stressed tomato plants showed increase in the levels of proline as compared with the nonstressed control plant. Proline accumulation is a common metabolic response to stress; many plants accumulate high amounts of proline in tissues if exposed to any stress (Pazarlar et al 2013). Proline accumulation in flax and faba bean plants with the rise of salinity levels were in contract with the results obtained by (Khalil, 2011).

Present work concerning the effect of CMV isolates on antioxidant enzymes activity in cucumber plant leaves, showed usually significant increase in the POX, PPO, SOD and CAT activity compared to the healthy ones(non-infected) at all tested plants. These results are in agreement with the study carried by (Huseynova and Aliyev 2012; Sofy et al 2017 and Sofy et al 2018). They observed that activities of leaf antioxidant enzymes have increased with stress. CAT and SOD were over-expressed due to infection of viral, demonstrating their role in detoxification of ROS. POX was reported to be the first enzyme to show changes in its activity under stress (Radwan et al 2007). So was considered POX one of the most important antioxidant enzymes involved in the plant defense response to pathogen attack. The increasing knowledge of plant defense mechanisms against pathogens is casting light on a process that appears to be more and more complex.

\section{CONCLUSION}

Both Cucumber-CMV and Squash-CMV isolates showed different impacts on photopigments, bioactive components and antioxidant enzymes activities in cucumber plants.

The most vital impact was Cucumber-CMV isolate.

\section{REFERENCE}

Afreen, B., Gulfishan, M., Baghel, G., Fatma, M., Akil Khan, A. and Naqvi, Q.A. 2011. Molecular detection of a virus infecting carrot and its effect on some cytological and physiological parameters. African J. of Plant Sci., 5, 407411.

Bates, L.S., Waldren, R.P. and Teare, I.D. 1973. Rapid determination of free proline for water stress studies. Plant Soil, 39, 205-207.

Bergmeyer, H.U. 1974. Methods of Enzymatic Analysis $1.2^{\text {nd }}$. Academic press. New York.

Chen, W.Y., Shenggen, H. and Su, Y. 2000. Effect of polyamines on biochemical and physiological changes and vas life of cut rose flowers during senescence. J. Tropical and Subtropical Bot. 8, $104-108$. 
Clark, M.F and Adam, N.E. 1977. Characterization of the microtitre plate method of enzyme linked immuno-assay (ELISA), for the detection of plant viruses. J. Gen. Virol. 37, 475-483.

Cornelia, H., Xinqiu, T., Deyong, Z., Charlotte, W., Peter, W. and Günter, A. 2012. A Comparative Testing of Cucumber mosaic virus (CMV)-Based Constructs to Generate Virus Resistant Plants. American J. of Plant Sci., 3, 461-472.

Daniel, H.D. and George C.M. 1972. Peach seed dormancy in relation to endogenous inhibitors and applied growth substances. J. Amer. Soc. Hort. Sci. 97, 651-654.

El-Dougdoug, K.A., Sofy, A.R., Mousa, A.A. and Refaey, E.E. 2014a. Monitoring variability responses of cultivated potato varieties infected with Potato virus $Y$ pepper isolate. Egyptian $\mathbf{J}$. Virol. 11, 82-101.

El-Dougdoug, N.K., Mahfouze, S.A., Ahmed, S.A., Othman, B.A. and Hazaa, M.M. 2014b. Characterization, Nucleotide Sequencing of Tomato Yellow Leaf Curl Virus Egyptian Isolate. Sci. Agri. 7, 58-69.

El-Dougdoug, N.K., Mahfouze, S.A., Ahmed, S.A., Othman, B.A. and Hazaa, M.M. 2013. Identification of Biochemical and Molecular Markers in Tomato Yellow Leaf Curl Virus Resistant Tomato Species. Sci. Agri. 2, 46-53.

FAO, 2016. FAOSTAT statistical database. Rome (available at http: //faostat. fao. org).

Farahat, A.S. 2017. Biological and molecular studies on cucumber mosaic cucumovirus in Egypt. M.Sc. Botany Dept. Sci. Fac., Mansura Univ., $140 \mathrm{p}$.

Gupta, U.P., Srivastava, M. and Gupta, U. 2010. Influence of Soybean Mosaic Virus Infection on Carbohydrate Content in Nodule of Soybean (Glycine $\max$ L. Merr.). Inter. J. of Viro. 6, 240- 245.

Härdle, W. and Simar, L. 2007. Applied Multivariate Statistical Analysis. $2^{\text {nd }}$ ed, Springer, 420 p.

Huseynova, I. and Aliyev, J. 2012. Evaluation of free radicals and antioxidant properties of virus infected food crops in azerbaijan. J. of Life Sci., 6, 1307-1316.

Kumar, A., Mali, P.C. and Manga, V.K. 2010. Changes of some phenolic compounds and enzyme activities on infected pearl millet caused by Sclerospora graminicola. Inter. J. Plant Physiol. Biochem. 2, 6-10.

Lowery, O.H., Rosebrough, N.J., Farr, A.L. and Randall, R.J. 1951. Protein measurement with the folin reagent. J. Biol. Chem., 193, 265-275.
Marklund, S. and Marklund, G. 1974. Involvement of the Superoxide Anion Radical in the Autoxidation of Pyrogallol and a Convenient Assay for Superoxide Dismutase. Eur. J. Biochem. 47, 469-474.

Matta, A. and Dimond, A. E. 1963. Symptoms of Fusarium wilt in relation to quantity of fungus and enzyme activity in tomato stems. Phytopathol. 53, 574-575.

Montasser, M.S., Al-own, F.D., Haneif, A.M. and Afzal, M. 2012. Effect of Tomato yellow leaf curl bigeminivirus (TYLCV) infection on tomato cell ultrastructure and physiology. Can.J. Plant Pathol. 34, 114-125.

Mukherjee, S.P. and Choudhuri, M.A. 1983. Implications of water stress-induced changes in the levels of endogenous ascorbic acid and hydrogen peroxide in Vigna seedlings. Physiol. Plant. 58, 166-170.

Palukaitis, P., Roossinck, M.J., Dietzgen, R.G., and Francki, R.I.B. 1992. Cucumber mosaic virus. Adv. Virus Res., 41, 281- 348.

Pazarlar, S., GÜmÜs, M. and Öztekin, G.B. 2013. The Effects of Tobacco mosaic virus Infection on Growth and Physiological Parameters in Some Pepper Varieties (Capsicum annuum L.). Not Bot. Horti. Agrobo. 41, 427433.

Radwan, D.E.M., Fayez, A.K., Mahmoud, Y.S. and Lu, G. 2010. Modifications in antioxidant activity and protein composition of bean leaf due to bean yellow mosaic virus infection and SA treatments. Acta Physiologae Plantarum 32, 315-324.

Radwan, D.E.M., Fayez, K.A., Mahmoud, S.Y., Hamad, A. and Lu, G. 2007. Physiological and metabolic changes of Cucurbita pepo leaves in response to Zucchini yellow mosaic virus (ZYMV) infection and salicylic acid treatments. Plant Physiol. Biochem., 45, 480-489.

Snedecor, G.W. and Cochran, W.G. 1973. "Statistical Methods". 6th ed., lowa State University Press, lowa, USA. 593 p.

Sofy, A.R., Attia, M.S., Sharaf, A.M.A. and ElDougdoug, K.A. 2014. Potential impacts of seed bacterization or salix extract in faba bean for enhancing protection against bean yellow mosaic disease. Nature and Sci., 12, 67-82.

Sofy, A.R., El-Dougdoug, K.A., Mousa, A.A. and Refaey, E.E. 2017. Impact of Two TYLCV Egyptian Isolates on Metabolic and Antioxidant Activities in Some Tomato Cultivars. Int. J. Adv. Res. Biol. Sci., 4, 110-133. 
Sofy, M.R., Abd El-Monem, M.A. Sharaf; Mohamed, E. E. and Sofy, A.R. 2018. Salix alba Extract Induces Systemic Resistance in $\mathrm{Cu}$ cumis sativus Infected by Cucumber mosaic virus. Nature and Sci., 16, 107-113.

Tajul, M.I., Naher, K., Hossain, T., Siddiqui, Y. and Sariah, M. 2011. Toamato yellow leaf curl virus (TYLCV) alters the phytochemical constituents in tomato fruits. AJCS pp. 575-581.

Umbriet, W.W., Burris, R.H., Stauffer, J.F., Cohen, P.P., Johsen, W.J., Lee page, G.A., Patter, V.R. and Schneicter, W.C. 1969. Monomeric techniques, manual describing methods applicable to the studs of tissue metabolism. Burgess publishing co., U.S.A; .239 p. 



\section{التغيرات الأيضيه في نباتات الخيار نتيجة الإصابة بعزلتين مصريتين \\ من فيروس تبرقش الخيار}

[150]

عبد الله سامي فرحات ${ }^{1}$ - عادل أحمد على المرسى 1 - هانى ايميل سويحه² - أحمد رمضان صوفى2 إيهاب إبراهيم الرفاعي المبئ

1- قسم النبات - كلية العلوم - جامعة المنصورة - المنصورة - مصر

2- قسم النبات والميكروبيولوجى - كلية العلوم (بنين) - جامعة الأزهر - القاهرة - مصر العرة

DAS-ELISA

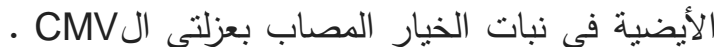

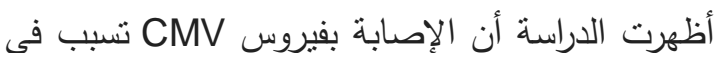
انخفاض كبير فى محتوى صنبغيات البنـاء الضونئى الإنى والمكونات الكيميائية الحيوية فى حين حلثت زين زيادة في

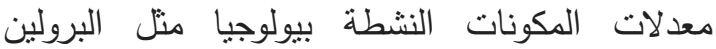
والفينول بالإضافة إلى الانزيمات المضادة للأكسدة مثل لكاتل

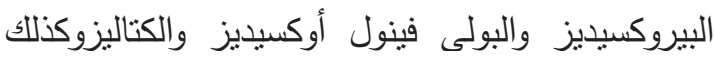

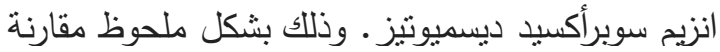

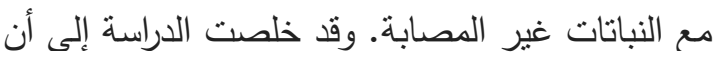
عزلة الخيار Cucumber-CMV - كانت أكثر تأثيرا

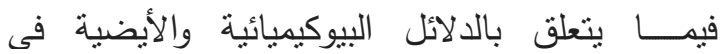
نباتات الخيار المصابة مقارنة بعزلة الكوسة الكانة .Squash-CMV
الكلمات الدالة: نبات الخيار، فيروس تبرقش الخيار ، إنزيمات الأكسدة، عزلات فيروس تبرقش الخيار، الاليزا

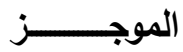

يتعرض إنتاج محصول نبات الخيار لخسائر فادحة فى مصر والعالم بسبب الإصابة بفيروس تبرقش الخيار (CMV) لذا فقد ركز البحث على دراسة تأثثير الثين الإنين من عزلات CMV المصرية على الأنشطة الأيضية

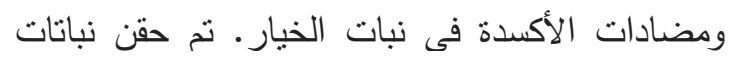
الخيار ميكانيكيا بواسطة العصبر الخام المعدي باتثنين

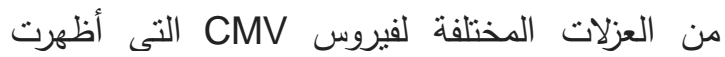
اختلافا فى الأعراض الخارجية. نم الكثف عن إصابة نباتات الخيار باثثين من عزلات CMV باستخدام تقنية 
